\title{
An Evaluation of Los Angeles's Orange Line Busway
}

\author{
Richard Stanger, Consultant
}

\begin{abstract}
The new 14.2-mile Orange Line Busway opened in October 2005. Many aspects of the Orange Line's design should be copied elsewhere: its attractive guideway and stations, state-of-the-art buses, proof-of-payment fare collection, and well-done environmental mitigations. On the other hand, a typical Orange Line bus trip catches about 11 red lights and waits up to nine minutes for them to change. Its end-to-end travel speed is $20 \mathrm{mph}$. The travel time is also compromised by a $25 \mathrm{mph}$ speed restriction at all intersections and speed limits along other portions of the busway.

The lesson of the Orange Line to transit planners is that an at-grade busway will almost certainly not get signal preemption. This means it will not have the crossing gates that allow its buses to cross intersections at speed. Therefore, every other effort should be made to increase a busway's travel speed through off-board fare collection, well-located platforms, minimal speed restrictions, and quick transferring to connecting services. A busway will be less expensive to build than a light rail alternative, but without signal preemption its travel speed will be significantly less.

A light rail alternative for the Orange Line would have had required crossing gates. Even if trains operated at the same lower speeds as buses within median rights-ofway, they would have been much faster (29 $\mathrm{mph}$ ) and offered a more stable ride quality.
\end{abstract}




\section{Introduction}

This article reviews the operation of Los Angeles's new Metro Orange Line busway. It is intended to help transit planners assess both the benefits and drawbacks of such a project. Local conditions will always determine the design specifics of a capital project, but often designs in one community build from designs-good or bad-for similar facilities elsewhere. The article also examines the supposition that the Orange Line operates like a light rail line.

\section{Project Description}

The Orange Line is a 14.2-mile busway on an old railroad right-of-way running east-west across Los Angeles's San Fernando Valley. Its eastern end feeds the northern terminus of the Red (rapid transit) Line to downtown Los Angeles; its other end serves Warner Center, a locus of office towers to the west (see Figure 1). The project serves several colleges and civic centers along its routes, but the predominant adjacent land use is residential. In June 2006, the busway carried almost 21,000 daily trips.

Operationally, the Orange Line is an end-to-end trunk line using articulated, low-floor buses. Its scheduled run time is 42 minutes. Its headways are 5 minutes during the peaks, 10 minutes mid-day, and 20 minutes after 7:45 pm. The right-ofway has 33 street crossings, and bus speeds at these crossings are restricted to 25 mph by policy. After several early car-bus accidents, the crossing speed was further restrained to $10 \mathrm{mph}$, but this is expected to be temporary. Buses operate between crossings at maximum speeds of either $35 \mathrm{mph}$ (within the median of a city street), $45 \mathrm{mph}$, or $55 \mathrm{mph}$ depending on the line section.

The service was the result of a 20-year effort to clear and approve a light rail line. Perhaps for this reason the new service was described as "a train on rubber tires" during start-up ceremonies (Fanfare Greets Start of Orange Line Buses 2005, quote by MTA Chief Executive Director Roger Snoble). The articulated buses were "to mimic the metallic look and spacious feel of a passenger rail car" (Fanfare Greets Start of Orange Line Buses 2005, description of buses by staff writer Caitlin Liu). The line was named a color as are the Los Angeles County Metropolitan Transit Authority's (MTA) subway and light rail lines and is shown on the MTA's rail system maps. 


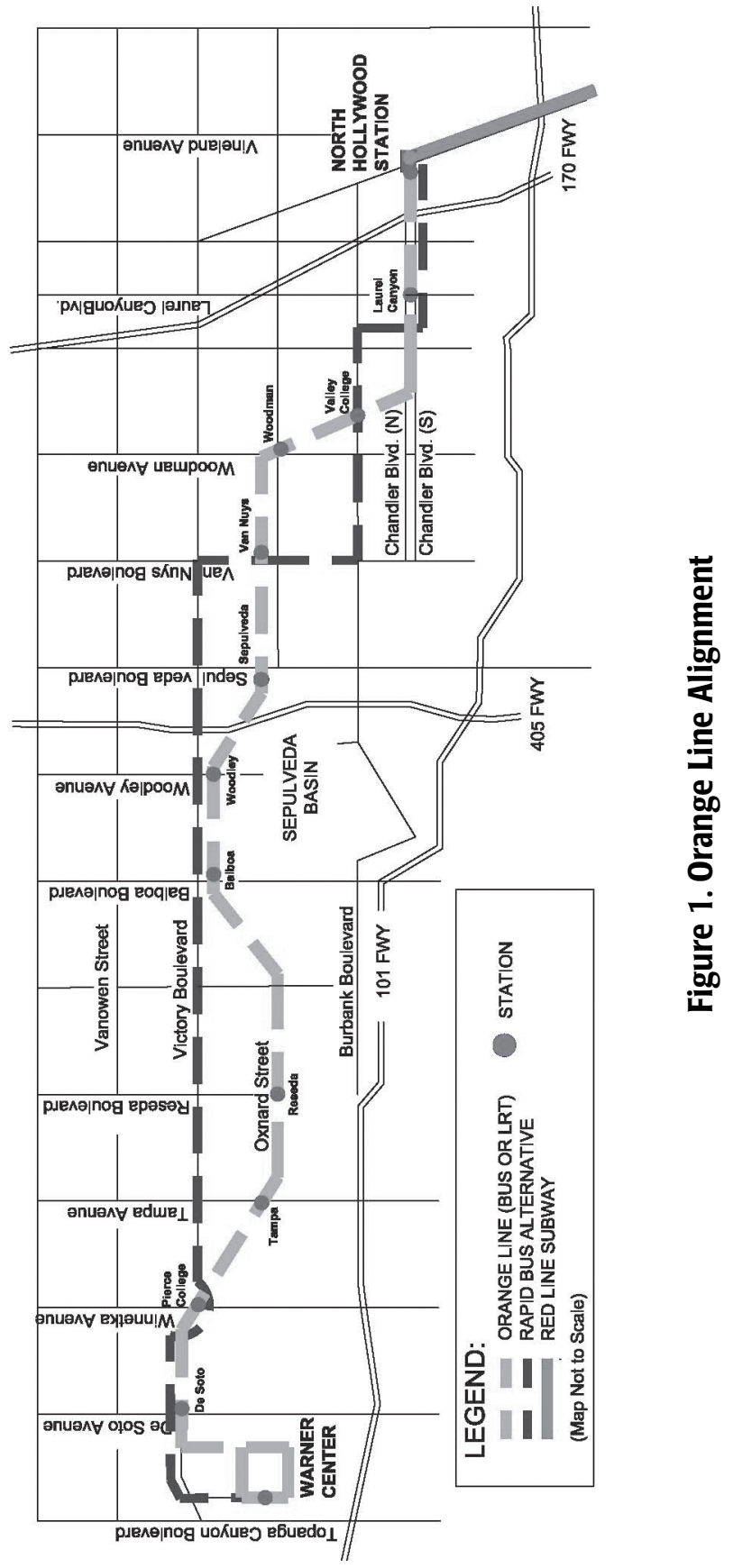




\section{History of Planning the Orange Line}

Proposition A was approved by Los Angeles County voters in 1980. It provided a half-cent sales tax in part for a rail system to be built within 13 designated "Prop A" corridors. One of these broad corridors was east-west across the San Fernando Valley from North Hollywood to the Warner Center area. In 1984 it was designated one of six high-priority corridors for implementation. The preferred alignment within this corridor was Southern Pacific's Burbank Branch, and the preferred mode was light rail.

Transit planners began developing a light rail line generally following the Burbank Branch right-of-way in 1985. Years of planning efforts followed. Community opposition to the rail project centered on the perception of lowered property values and system noise, although a general fear of change was also apparent. Major related reports were published in 1986, 1987, 1990, 1992, 1994, 1998, and 2000. The last report was the first to adopt a busway concept. The communities resisted the busway as well, but after 15 years of fighting, they realized some improvement was inevitable-and the MTA forcefully resisted further opposition. The decision to build the line was made in 2001, construction started in 2002, and the busway was inaugurated in October 2005.

Little discussion of bus operations is found in the environmental documents. Summary tables project end-to-end travel times between 28.8 minutes and 40.0 minutes. ${ }^{2}$ The goal of the project was very fast service. There is no indication in the environmental documents that bus cruising speeds would be limited to $35 \mathrm{mph}$ and $45 \mathrm{mph}$ for most of the busway. Nor is there any indication that bus crossing speeds would be restricted to $25 \mathrm{mph}$ at all intersections. As to signal priority, there is only this disclaimer: "Precise signal timing and priority parameters would not be set until just prior to the commencement of BRT operations and would likely be adjusted throughout the life of the project." ${ }^{3}$

\section{The Busway Design}

In designing the busway, engineers had the advantage of being able to use an existing railroad right-of-way across an almost flat urban setting. The right-of-way is typically 100 feet wide, but varies from 70 to 200 feet. The bus roadway itself is 26 feet wide with one lane in each direction. At platforms, the roadway widens on one side to 23 feet, which allows a bus to pass another in case of breakdowns. There are also 50 pullouts along the busway primarily for maintenance vehicles to 
park; these are typically 70 -feet long and 10-feet deep. The alignment is capable of supporting maximum operating speeds of $55 \mathrm{mph}$.

The busway appears to be an asset to the communities along it route. It provides easy east-west access to important Valley destinations. It replaces an unused dirt right-of-way prone to trash dumping with a very attractively landscaped improvement offering some sound walls, pedestrian crosswalks, and the continuous bikeway. Unlike a light rail line (or the freight train traffic up to the late 1980s), there is no mandated horn noise associated with bus crossings at intersections.

\section{Busway Stations and Access}

The Orange Line has 12 stations within the railroad right-of-way portion of the line. Each has sidewalk-level platforms, canopied, long enough for two buses, and equipped with passenger information displays. Fare collection is by off-bus ticket vending machines and fare enforcement is proof of payment (on-board random checking with fines). Table 1 summarizes the platform location and access facilities of the stations.

\section{Table 1. Busway Station Characteristics}

\begin{tabular}{|c|c|c|c|}
\hline Station & Platform Location & $\begin{array}{l}\text { Connecting N-S } \\
\text { Bus Routes }{ }^{1}\end{array}$ & Parking \\
\hline Warner Center & Sidewalk & 8 & No \\
\hline DeSoto Avenue & Far Side & 2 & No \\
\hline Pierce College & Far Side & 1 & No \\
\hline Tampa Avenue & Far Side & 1 & No \\
\hline Reseda Avenue & Far Side & 1 & 100 \\
\hline Balboa Avenue & $\begin{array}{l}\text { Westbound-Near Side } \\
\text { Eastbound-Far Side }\end{array}$ & 4 & 150 \\
\hline Woodley Avenue & Far Side & 1 & No \\
\hline Sepulveda Avenue & Not at Cross Street & 1 & 1,179 \\
\hline Van Nuys Blvd. & $\begin{array}{l}\text { Westbound-Near Side } \\
\text { Eastbound-Far Side }\end{array}$ & 7 & 824 \\
\hline Woodman/Oxnard & Westbound-Near Side & & \\
\hline Valley College & $\begin{array}{l}\text { Eastbound-Far Side } \\
\text { Westbound-Near Side }\end{array}$ & 1 & No \\
\hline & Eastbound-Far Side & 3 & No \\
\hline Laurel Canyon & Far Side & 1 & No \\
\hline North Hollywood & Near Side Terminal & $\begin{array}{c}1 \text { convenient, } \\
6 \text { others, Red Line }\end{array}$ & $K \& R$ \\
\hline
\end{tabular}

1. Local bus route 164 parallels the Orange Line from Warner Center along Victory to the Sepulveda and Van Nuys Stations. Local bus route 156 parallels the line from Van Nuys to North Hollywood.

2. A major bus center is located east of the Red Line Station, but it starts 400 feet from the busway alighting platform west of Lankershim Boulevard. 


\section{The Traffic Signal Control System}

The City of Los Angeles Department of Transportation(LADOT) now has 3,200 of its 4,300 intersections tied into its Automated Traffic Surveillance and Control (ATSAC) system. The ATSAC system improves the flow of traffic by coordinating the phasing and timing of green lights. LADOT developed an added feature, the Transit Priority System (TPS), to ATSAC to give buses on key bus routes up to 10 percent more signal cycle time if delayed. The Orange Line busway crossing signals are tied into the ATSAC/TPS system.

LADOT modeled a possible busway before it was officially adopted by the MTA. From this work, it was determined that signal priority was possible for the busway, but not full-signal preemption (any approaching bus causes crossing motorists to stop). LADOT calculated a total of one million daily north-south auto trips across the 33 Orange Line intersections; these trips needed as much green signal time as possible. Traffic engineers also recommended far-side platforms wherever possible because it would be more difficult to pretime the following traffic signal with a near-side station dwell of unknown duration. Crossing gates were considered, but were ruled out by LADOT because its traffic engineers felt that motorists did not require the same level of crossing protection from buses as they did from light rail trains. ${ }^{4}$ The need to lower crossing gates in advance of a bus's arrival would also unnecessarily lengthen delays to the heavy north-south traffic. Although LADOT made its decisions for the Orange Line, the resulting busway operation is similar to that of the South Miami Busway and may reflect an emerging consensus among traffic engineers on how an at-grade busway should be operated.

As the MTA conducted prerevenue operations testing, LADOT engineers refined the timing of the signal priority system. It operates a little like a "green wave" assuming that buses travel at their posted speeds, have station dwell times of about 20 seconds, and cross intersections at $25 \mathrm{mph}$. But even then LADOT engineers estimate that a bus trip typically catches red lights at a third of the intersections ( 11 red lights), an average consistent with a dozen field trips made. The system is also designed to retain the scheduled headway. This means that if a bus is behind schedule, it is given more green time to help it catch up to the timetable, but the trailing buses are given no priority to preserve the timetable. If a lead bus is well behind schedule, all the following buses may be as well-but evenly spaced. The LADOT's traffic monitoring center can follow the movement of each Orange Line bus by its on-board transponders and intersection cameras. The transponders 
are also used to inform patrons when the next bus is due using automated station message boards.

\section{Project Costs}

The forecasted construction cost of the project is $\$ 290$ million. It was funded through local Proposition C ( $\$ 150.2$ million), State of California ( $\$ 145.0$ million), and federal ( $\$ 17.5$ million) dollars. ${ }^{5}$ Table 2 shows the project's costs by major cost categories.

\section{Table 2. Orange Line Project Forecasted Costs (millions)}

\begin{tabular}{lccl}
\hline Cost Component & Current Forecast $^{1}$ & Percentage of Total & Cost per Unit $^{2}$ \\
\hline Guideway & $\$ 136.2$ & $34.8 \%$ & $\$ 10.1 / \mathrm{bswy}_{\text {-mile }}$ \\
Systems and Equipment & $\$ 9.1$ & $2.3 \%$ & $\$ 0.7 / \mathrm{bswy}$-mile \\
Stations & $\$ 30.4$ & $7.8 \%$ & $\$ 2.3 /$ station \\
Vehicles and Buses & $\$ 16.7$ & $4.3 \%$ & $\$ 1.1 / \mathrm{mile}$ \\
Special Conditions3 & $\$ 34.6$ & $8.9 \%$ & $\$ 2.4 / \mathrm{mile}$ \\
Misc. Rights-of-Way & $\$ 13.4$ & $3.4 \%$ & $\$ 1.0 / \mathrm{bswy}$-mile \\
Yards and Shops & $\$ 1.2$ & $0.3 \%$ & $\$ 1.2 / \mathrm{project}$ \\
Professional Services & $\$ 47.0$ & $12.1 \%$ & $\$ 3.3 / \mathrm{mile}$ \\
Contingency & $\$ 2.1$ & $0.5 \%$ & $\$ 0.2 / \mathrm{mile}$ \\
Subtotal & $\$ 290.0$ & $74.4 \%$ & $\$ 19.4 / \mathrm{mile}$ \\
RR, Drive-in, and Misc. & $\$ 100.0$ & $25.6 \%$ & $\$ 7.4 / \mathrm{bswy}$-mile \\
Rights-of-Way & & & \\
\hline Total & $\$ 390.0$ & $100.0 \%$ & $\$ 27.4 / \mathrm{mile}$ \\
\hline
\end{tabular}

1. See Los Angeles County Metropolitan Transportation Authority. 2006. Quarterly project status report, Metro Orange Line, June 2006. Project Cost Status Table, p. 4.

2. "Bswy-mile" = mileage of busway itself (13.5), "miles" = project miles (14.2).

3. Includes costs associated with environmental mitigation and compliance, master cooperative agreements, insurance programs, safety program, artwork, and systems integration testing.

In 1990 the LACTC purchased the entire 20-mile Burbank Branch and adjacent railroad properties for $\$ 122.1$ million. Of the busway's 14.2 miles, 13.5 miles were built on the right-of-way, which can be conservatively valued at $\$ 85$ million. The Sepulveda Boulevard Station's parking lot-an old drive-in theater-was purchased in 1991 for about $\$ 15$ million. These costs do not show up in the official project budget, but have been included in Table 2 . 
The $\$ 27.4$ million per mile for the Orange Line is substantially less than MTA's cost per mile for its light rail lines. The Gold Line averaged about $\$ 65$ million per mile, all costs included, and the Blue Line around $\$ 45$ million, both in earlier dollars. The Exposition Line is projected to cost $\$ 70$ million per mile by the time it starts operations in 2010. At $\$ 65$ million per mile, an Orange (light rail) Line would have cost $\$ 925$ million.

The City of Los Angeles contributed an additional \$10.6 million for the bikeway. Portions of the bikeway already existed and others used existing city streets. The newly built segments totaled 8.2 miles, an average of $\$ 1.3$ million per mile.

\section{Busway Operations}

The Orange Line operates as a trunk line feeder to the Red Line. Only new, articulated, low-floor buses painted specially for this service use the busway. Other buses do not merge into the busway at interim stations. However, the type of service one would associate with a busway (or light rail line) operating over its own right-ofway-high operating speeds and no delays-is compromised on the Orange Line in five ways.

\section{Signal Priority}

LADOT feels that blending the busway into its ATSAC/TPS system is the optimal solution. But it is disconcerting that buses catch an average of 11 red lights per trip. These delays are compounded because half the red light delays occur just before a subsequent far-side station dwell.

\section{Restrictions to Maximum Speed}

Maximum speeds are restricted along most portions of the busway to conform to neighborhood desires or to provide additional safety. Buses proceed at 35 mph from the North Hollywood Station along Chandler Boulevard to Woodman Avenue (2.6 miles), the most community-sensitive portion of the Line; $45 \mathrm{mph}$ from Woodman Avenue to Sepulveda Boulevard (2.9 miles); $55 \mathrm{mph}$ through the Sepulveda Basin ( 4.2 miles); then back to $45 \mathrm{mph}$ from Reseda Boulevard to the end of the busway ( 3.8 miles).

\section{Slowing at Grade-Crossings}

All Orange Line buses initially slowed to $25 \mathrm{mph}$ at all intersecting streets. The reason given for this is that bus-car accidents are more dangerous for bus passengers (than for light rail passengers) and more caution is therefore needed. After a series 
of bus-car accidents in the first month of operation, the bus crossing speed was (temporarily) dropped to $10 \mathrm{mph}$. (In practice, bus drivers rarely cross an intersection below 15-20 mph, in part because the timetable and the ATSAC system timing were not changed.)

\section{North Hollywood Station Terminal Design}

The east end of the Orange Line ends just west of Lankershim Boulevard (see Figure 2). Across the street are the Red Line Station entrances and, further east, the Red Line's bus center where six bus routes come together. Most Orange Line riders transfer to (or from) the Red Line and must walk at least 400 feet to the Red Line escalators and cross busy Lankershim Boulevard. An additional 150 feet more is required to get to and from the bus center. Three reasons are given by planners and engineers for this design:

1. A west-side pedestrian entrance to the Red Line mezzanine was planned, but its estimated $\$ 10$ million cost was not affordable.

2. If the busway were to continue across Lankershim Boulevard, the Red Line station's entrance plaza would have had to be reconfigured or even sacrificed.

3. Another intersection with Lankershim Boulevard would have been too disruptive for traffic in this busy area.

None of these points seem to outweigh the huge on-going passenger inconvenience caused by this poor interface.

\section{Bicycle Policy}

Because of the side sway of a bus, bicycles brought on-board must be anchored for passenger safety. The bus driver must leave his seat and supervise the loading; unloading is typically done by the bicycle's owner. The results are station dwell times of 2 to 3 minutes for bicycle loading (compared with wheelchair loading times of less than a minute). The resulting scheduled delays, albeit only on occasional trips, makes this policy decision questionable.

\section{Alternative Busway Operating Scenarios}

Using engineering drawings of the busway, a run-time model was developed that allows the effects of different operating assumptions to be compared (Los Angeles County Metropolitan Transportation Authority 2002). The model calculates the accelerating, cruising, and braking times and distances for each line segment that 


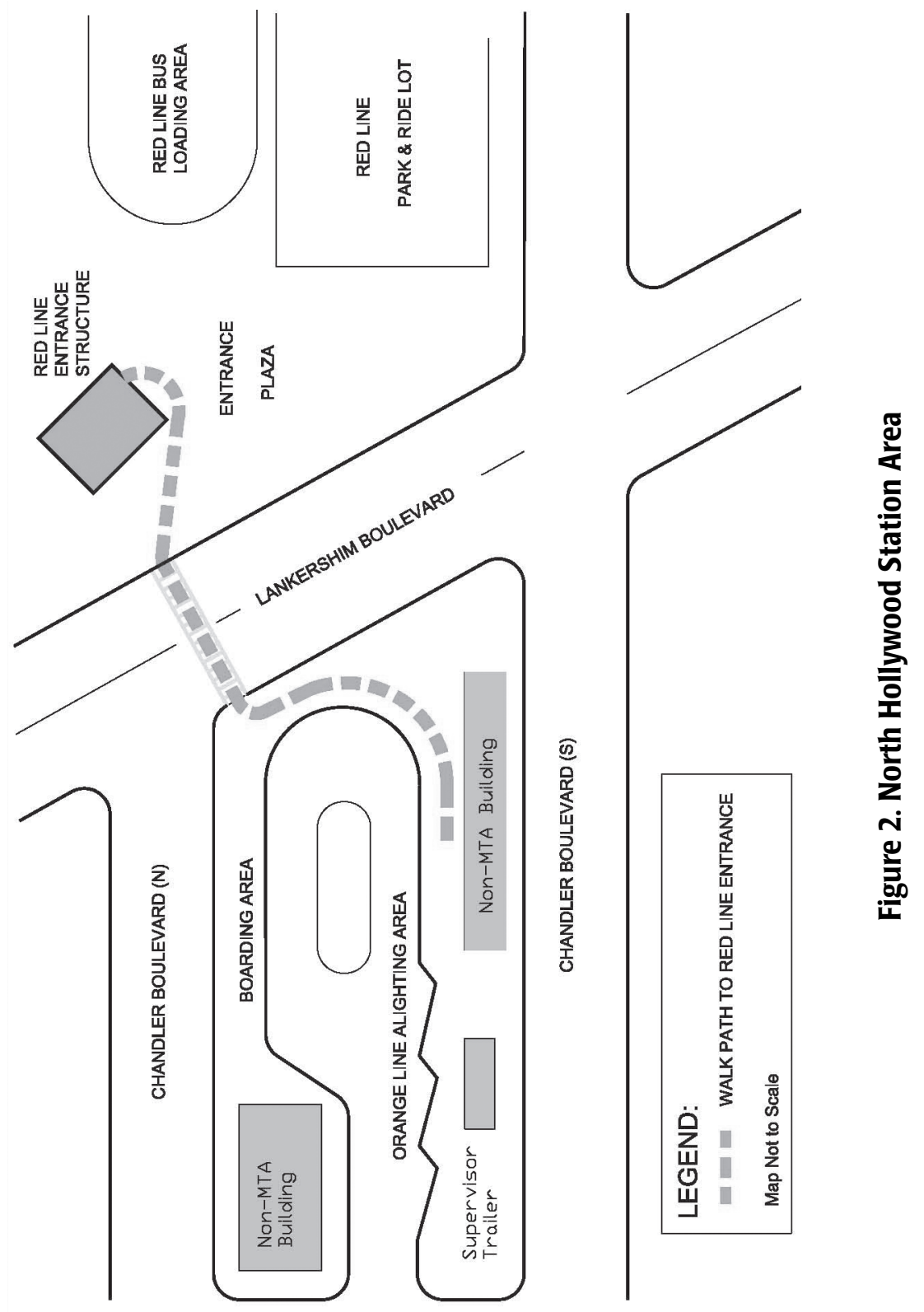


requires the bus to alter speed (e.g., intersections, stations, curves). ${ }^{6}$ It accumulates these times (plus station dwell) and distances over the length of the project. The model also incorporates "delay" time caused by red lights, etc. The result was calibrated against the Orange Line timetable by making adjustments to the "delay" times. Below are descriptions of the operating scenarios evaluated. They are summarized in Table 3.

- Existing Service (Base Case). $25 \mathrm{mph}$ at cross streets, restricted maximum speeds, experienced delays from red lights, and 20-second average dwells.

- Buses Slowing to 10 mph at Crossings. Same as the base scenario except that buses slow to $10 \mathrm{mph}$ at crossings, the temporary condition.

- Signal Preemption. No red lights are encountered, buses slow to $25 \mathrm{mph}$ at street crossings. The difference between the base case time and this run's time approximates the total delay for expected red light delays.

- Speed at Crossings. This means, for example, in the $35 \mathrm{mph}$ maximum speed zone, buses cross an intersection at $35 \mathrm{mph}$.

- 55 mph Through Intersections. This scenario treats the buses the same as light rail trains, and would probably require gated crossings at all intersections.

\section{Table 3. Assumptions for Alternative Busway Operating Scenarios}

\begin{tabular}{lccccc}
$\begin{array}{l}\text { Operating } \\
\text { Scenario }\end{array}$ & $\begin{array}{c}\mathbf{2 5} \mathbf{\text { mph}} \\
\text { at Crossings }\end{array}$ & $\begin{array}{c}\text { Signal } \\
\text { Priority }\end{array}$ & $\begin{array}{c}\text { Restricted } \\
\text { Max Speed }\end{array}$ & $\begin{array}{c}\mathbf{2 0 - S e c} \\
\text { Dwell }\end{array}$ & $\begin{array}{c}\text { Gated } \\
\text { Crossings }\end{array}$ \\
\hline Base: Existing Service & yes & existing & yes & yes & no \\
$10 \mathrm{mph}$ Crossings & no & existing & yes & yes & no \\
Signal Preemption & yes & complete & yes & yes & no \\
Speed at Crossings & no & complete & yes & yes & 1 \\
55 mph Throughout & no & complete & $55 \mathrm{mph}$ & yes & all \\
\hline
\end{tabular}

Table 4 summarizes the resulting end-to-end travel times. The initial operating scenario is the base case, and its run time is 42 minutes as per the timetable. Giving Orange Line buses signal preemption-even though crossing speeds remain $25 \mathrm{mph}$-would save the most amount of time and raise the average travel speed the most. Allowing buses to cross intersections at the prevailing posted busway speeds further lowers travel time by 2.4 minutes. Finally, allowing buses to travel at a maximum speed of $55 \mathrm{mph}$ throughout lowers travel time only 1.8 minutes 
more. Table 4 illustrates the importance of getting buses through red lights: up to 9 minutes could be saved if there were none.

\section{Table 4. Busway Time Savings/Losses with Various Operating Assumptions}

\begin{tabular}{lcccc} 
Busway Operating & $\begin{array}{c}\text { End-to-End } \\
\text { Travel Time } \\
\text { (minutes) }\end{array}$ & $\begin{array}{c}\text { Average } \\
\text { Travel Speed } \\
(\mathbf{m p h})\end{array}$ & $\begin{array}{c}\text { Additional } \\
\text { Time Savings } \\
\text { (minutes) }\end{array}$ & $\begin{array}{c}\text { Additional } \\
\text { Time Savings } \\
\text { (\%) }\end{array}$ \\
\hline 10 mph Crossings & 46.6 & 18 & -4.6 & $-11 \%$ \\
Base: Existing Service & 42.1 & 20 & 0.0 & $0 \%$ \\
Signal Preemption & 32.7 & 26 & +9.4 & $+22 \%$ \\
Speed at Crossings & 29.7 & 29 & +3.0 & $+7 \%$ \\
55 mph Throughout & 27.8 & 31 & +1.9 & $+5 \%$
\end{tabular}

\section{Alternative Light Rail Scenarios}

The Orange Line has been described as a rail line using rubber tires. Is it? To determine the travel times for the Orange Line were it in fact light rail, the same travel time model was used, but with the acceleration/deceleration profiles of the MTA's light rail vehicles. As is standard design for light rail, all intersections have crossing gates that give light rail trains automatic signal preemption. Is it fair, then to compare the Orange Line without signal preemption with LRT with it? Yes, because each is being operated as it normally would in an urban setting. Table 5 summarizes the LRT operating scenarios.

\section{Table 5. Assumptions for Alternative Light Rail Operating Scenarios}

\begin{tabular}{lccccc}
$\begin{array}{l}\text { Operating } \\
\text { Scenario }\end{array}$ & $\begin{array}{c}\mathbf{2 5} \mathbf{\text { mph}} \\
\text { at Crossings }\end{array}$ & $\begin{array}{c}\text { Signal } \\
\text { Priority }\end{array}$ & $\begin{array}{c}\text { Restricted } \\
\text { Max Speed }\end{array}$ & $\begin{array}{c}\text { 20-Sec } \\
\text { Dwell }\end{array}$ & $\begin{array}{c}\text { Gated } \\
\text { Crossings }\end{array}$ \\
\hline Speed at Crossing & no & complete & yes & yes & all \\
$55 \mathrm{mph}$ Throughout & no & complete & $55 \mathrm{mph}$ & yes & all \\
$65 \mathrm{mph}$ Throughout & no & complete & $65 \mathrm{mph}$ & yes & all
\end{tabular}

The resulting travel times are shown in Table 6 . The base case for light rail results in an end-to-end travel time of 29 minutes. This time includes the $35 \mathrm{mph}$ running along Chandler, $45 \mathrm{mph}$ to Sepulveda, and $45 \mathrm{mph}$ between White Oak and the 
end of the railroad right-of-way. Allowing the light rail trains to travel at $55 \mathrm{mph}$ throughout (except, of course, in Warner Center) lowers the total travel time by another 2.2 minutes.

\section{Table 6. Light Rail Time Travel Times with Various Operating Assumptions}

\begin{tabular}{lcccc}
$\begin{array}{l}\text { Light Rail } \\
\text { Operating Scenario }\end{array}$ & $\begin{array}{c}\text { End-to-End } \\
\text { Travel Time } \\
\text { (minutes) }\end{array}$ & $\begin{array}{c}\text { Average } \\
\text { Travel Speed } \\
(\mathbf{m p h})\end{array}$ & $\begin{array}{c}\text { Additional } \\
\text { Time Savings } \\
\text { (minutes) }\end{array}$ & $\begin{array}{c}\text { Additional } \\
\text { Time Savings } \\
\text { (\%) }\end{array}$ \\
\hline Speed at Crossing & 29.0 & 29 & - & - \\
55 mph Throughout & 26.8 & 32 & +2.2 & $+8 \%$ \\
65 mph Throughout & 26.5 & 32 & +0.3 & $+1 \%$
\end{tabular}

The Orange (busway) Line's operating performance cannot be compared favorably to an Orange (light rail) Line's performance. A light rail line is much faster and more reliable because its crossing gates would allow it to avoid red lights. (Both wheelchairs and bicyclists could also board and alight within a normal 20-second station dwell.)

\section{Comparison with a Rapid Bus Route}

Local bus route 164 serves the Warner Center transit hub and from there to Van Nuys Boulevard it parallels the Orange Line alignment and serves four of its stations directly. It arrives at Van Nuys and Victory, one-half mile north of the busway station, and, were it to turn south, it could serve the Van Nuys Station within 34 minutes. Local bus route 156 serves the Van Nuys Station and then proceeds south and east to the North Hollywood Station. The end-to-end travel time of the combined two local routes is 57 minutes over a 15.4-mile length. The combined route would directly serve nine of the Orange Line's 13 stations and be within one-half mile of the others.

If the combined route were to be converted into a rapid bus service, however, its end-to-end travel time would be much closer to the busway's. To calculate its run time, the run-time model was calibrated for local bus routes 164 and 156 . Then the number of bus stops was reduced from the existing 3.7 per mile to 1 per mile, the same spacing as the Orange Line. The same speed restrictions and signal delays encountered with the local buses were retained, although a rapid bus service 
would receive some level of signal priority not calculated here. Orange Line articulated bus speed profiles were also substituted for regular local bus profiles.

The results are shown in Table 7. The end-to-end travel time drops to 44 minutes, almost that of the busway's travel time. Capital costs associated with a rapid bus line would be an estimated $\$ 50$ million including new buses, passenger information systems, upgraded stations/stops and support facilities.

\section{Table 7. Rapid Bus Time Travel Time}

\begin{tabular}{lcccc} 
Bus Scenario & $\begin{array}{c}\text { End-to-End } \\
\text { Travel Time } \\
\text { (minutes) }\end{array}$ & $\begin{array}{c}\text { Average } \\
\text { Travel Speed } \\
(\mathbf{m p h})\end{array}$ & $\begin{array}{c}\text { Additional } \\
\text { Time Savings } \\
\text { (minutes) }\end{array}$ & $\begin{array}{c}\text { Additional } \\
\text { Time Savings } \\
(\%)\end{array}$ \\
\hline Local Bus \#164 \& 156 & 57 & 16 & - & - \\
Rapid Bus Route & 44.4 & 21 & +12.6 & $+22 \%$
\end{tabular}

The rapid bus alternative does have operational limitations. It is not on a protected, well-defined, transitway, which in and of itself is a great benefit to the San Fernando Valley. Over time, as San Fernando Valley traffic congestion builds, the rapid bus line may also become a slower service.

\section{Summary}

Table 8 presents the various travel times for all Orange Line options and their estimated costs. While the Orange Line does provide travel times substantially less than local bus services, it is not much better now than a rapid bus service. Light rail would have been the fastest and most reliable alternative, taking advantage of rail's crossing gates and better rate of acceleration. Its capital cost, however, would have been the highest of all alternatives. Much of the cost for both the busway and the light rail alternatives entails assuring long-term schedule reliability, and this must be factored into any evaluation. The busway in turn should be more reliable than a rapid bus service operating on city streets. 


\section{Table 8. Summary of Orange Line Alternatives}

\begin{tabular}{|c|c|c|c|c|}
\hline Operating Scenario & $\begin{array}{l}\text { End-to-End } \\
\text { Travel Time }\end{array}$ & $\begin{array}{l}\text { Average } \\
\text { Speed }\end{array}$ & $\begin{array}{l}\text { Estimated } \\
\text { Capital Cost }\end{array}$ & $\begin{array}{l}\text { Long-term } \\
\text { Reliability }\end{array}$ \\
\hline $\begin{array}{l}\text { Existing Bus Routes } \\
164 \text { and } 156\end{array}$ & 57 minutes & $16 \mathrm{mph}$ & - & Low \\
\hline Rapid Bus & 44 minutes & $20 \mathrm{mph}$ & $\begin{array}{l}\$ 50 \text { million } \\
\text { (estimate) }\end{array}$ & Fair \\
\hline Busway & 42 minutes & $20 \mathrm{mph}$ & $\$ 390$ million & Good \\
\hline Light Rail & 29 minutes & $29 \mathrm{mph}$ & $\begin{array}{l}\$ 925 \text { million } \\
\text { (estimate) }\end{array}$ & Very Good \\
\hline
\end{tabular}

\section{Conclusions}

The Orange Line is a significant transit addition to the San Fernando Valley, providing direct access for communities along its route to important centers as well as to the Red Line. It is well designed as a roadway, well landscaped, and offers additional community benefits. It uses state-of-the-art, low-floor buses and takes advantage of the guideway and buses by using proof-of-payment fare collection. It is important to emphasize that planning of the Orange Line was a collaborative effort between the MTA and LADOT.

The operation of the Orange Line has been compromised, however, by a signal priority system that ended up less than what its planners and officials anticipated. It is here where other systems can learn important lessons.

- Traffic engineers appear to be very reluctant to give busway buses signal preemption with or without crossing gates. As a result, potential travel speeds on an at-grade busway are substantially compromised.

- A transit agency should be reluctant to build a busway without guarantees that signal preemption will be provided. But if it goes ahead with less than preemption, it should do a careful study of how to minimize delays: closing crossings, the fewest possible red lights, well-located platforms to minimize the double-stop penalty of far-side stops, quick and easy transferring at end-points, and fare collection and other policies that lessen delays. If signal preemption cannot be obtained during peak periods, it may well be acceptable off-peak and on weekends.

- When spending so much for a busway, crossing gates for buses are a good 
investment to assure full signal preemption and higher operating speeds. This is the case even if bus speeds are restricted at crossings.

The analysis also shows it is not correct to equate the Orange Line Busway (or any similar at-grade busway) with a light rail line. Instead of an average end-to-end trip time of 42 minutes ( $20 \mathrm{mph}$ ), even a speed-restricted light rail line would have taken no more than 29 minutes $(29 \mathrm{mph}$ ), a 31 percent drop in travel time. The ride quality of a light rail line would also be better.

This analysis does not conclude that the Orange Line should have been a light rail line. The Orange Line could not have been a light rail line because community opposition to that mode was clear and enduring. Nor does the analysis conclude that the Orange Line busway should not have been built; the San Fernando Valley is better served by a busway than a rapid bus route on ever-congested city streets. Given the availability of the Burbank Branch right-of-way, not using it as some form of transitway would have been unthinkable.

The MTA must continue to find ways to increase the Orange Line's travel speeds, correct the very unfortunate North Hollywood Station transfer, and seek increased signal priority for its buses, up to and including crossing gates.

\section{Endnotes}

${ }^{1}$ In June 2006 the MTA changed the Orange Line's timetable. In the eastbound direction and throughout the day, up to 3 minutes were added to the earlier run times, often all 3 minutes between the last two stations. In the westbound direction run times decreased by up to 2 minutes, but never increased. For this analysis the original 42-minute schedule is used.

${ }^{2}$ See Los Angeles County Metropolitan Transportation Authority 2004, Table RS4a: Refinements to Locally Preferred Alternative.

${ }^{3}$ See Los Angeles County Metropolitan Transportation Authority 2004.

${ }^{4}$ Crossing gates are required by the California Public Utilities Commission for light rail trains above $35 \mathrm{mph}$ in large part because a loaded light rail car weighs $110,000+$ pounds and a collision with a railcar may well be fatal. Bus movements are controlled locally by traffic engineers. (A loaded 60 -foot bus weighs 44,000 pounds.) 
${ }^{5}$ These figures total $\$ 313$ million, the total funds anticipated for the project. The forecasted budget was $\$ 290$ million in June 2006 with the project virtually complete.

${ }^{6}$ On the advise of MTA staff, the model used the APTA guidelines for the acceleration and deceleration of articulated buses, which are compatible with Orange Line bus performance curves.

\section{References}

Fanfare Greets Start of Orange Line Buses. 2005. Los Angeles Times (October 29).

Los Angeles County Metropolitan Transportation Authority. 2002. San Fernando Valley east-west BRT project, bid-level drawings (June 14).

Los Angeles County Metropolitan Transportation Authority. 2004. Draft revised final environmental impact report Vol. 4, Chp. 8, p. RS-44 (October)

Los Angeles County Metropolitan Transportation Authority. 2006. Quarterly project status report, Metro Orange Line, June 2006.

\section{About the Author}

RICHARD STANGER (stangerr@verizon.net) is a transportation consultant in Los Angeles. He received a masters in both urban engineering and city planning from the University of Pennsylvania. Between 1985 and 1990 he was director of Rail Development with the Los Angeles County Transportation Commission and between 1990 and 1998 was executive director of the Southern California Regional Rail Authority (Metrolink). Over the years he has published a number of articles on various aspects of urban transit. 